\title{
Direct comparison of site-specific and basin-scale denudation rate estimation by in situ cosmogenic nuclides: an example from the Abukuma Mountains, Japan
}

\author{
Atsunori Nakamura ${ }^{1,2}$, Yusuke Yokoyama $^{1,2,3^{*}}$, Kazuyo Shiroya $^{4}$, Yosuke Miyairi ${ }^{1}$ and Hiroyuki Matsuzaki ${ }^{5}$
}

\begin{abstract}
Accurate determination of denudation rates is important in understanding Earth surface system dynamics. In situ produced cosmogenic nuclides, such as ${ }^{10} \mathrm{Be}$ and ${ }^{26} \mathrm{Al}$, provide a valuable insight but are not entirely free from complications. In this study, denudation rates are determined for the Abukuma Mountains, Japan, using both site-specific and basin-scale methods. Considered with density measured in the field, distinct and systematic differences between the two methods are identified. Site-specific rates calculated from depth profiles of cosmogenic nuclides $\left({ }^{10} \mathrm{Be}\right.$ and $\left.{ }^{26} \mathrm{Al}\right)$ at topographic highs indicate a rate of 67 to $85 \mathrm{~mm} / \mathrm{kyr}$, whereas basin-scale averaged denudation rates derived from the concentration of cosmogenic nuclides in fluvial sediments show 114 to $180 \mathrm{~mm} / \mathrm{kyr}$. This is the first comparison of these two commonly used methods in the same region in Japan, where the entire study area is characterized by well-developed saprolite. These results indicate that differential denudation rates between topographic highs and valleys reflect increasing local topographic relief of the study area. Comparison between rates derived from depth profiles and those applicable to the entire basin is important for understanding landscape development.
\end{abstract}

Keywords: Denudation rate; Erosion rate; In situ cosmogenic nuclide; ${ }^{10} \mathrm{Be}$ and ${ }^{26} \mathrm{Al}$; Depth profile; Density

\section{Background}

Site-specific and basin-scale denudation rates

Quantifying denudation rates is important across a diverse range of disciplines in geology, geomorphology, and paleoclimatology (Yokoyama et al. 2005; Yokoyama and Esat 2011). Denudation is often associated with sediment generation, which exposes fresh rock to $\mathrm{CO}_{2}$ consuming weathering reactions, and with creating soil, changing landforms, and moving mass from continents to oceans (Berner et al. 1983; Matsumoto and Yokoyama 2013). While numerous studies underline the significance and complexity of relationships between denudation, tectonics, and climatic processes (e.g., Granger and Riebe 2007 and references therein; Shiroya et al. 2013),

\footnotetext{
* Correspondence: yokoyama@aori.u-tokyo.ac.jp

${ }^{1}$ Atmosphere and Ocean Research Institute, University of Tokyo, 5-1-5

Kashiwanoha, Kashiwa, Chiba 277-8564, Japan

${ }^{2}$ Department of Earth and Planetary Science, Graduate School of Science,

University of Tokyo, 7-3-1 Hongo, Bunkyo-ku, Tokyo 113-0033, Japan

Full list of author information is available at the end of the article
}

determination of long-term denudation rates over the timescales of soil formation and transport has, until recently, remained difficult. In situ cosmogenic nuclide concentrations such as ${ }^{10} \mathrm{Be}$ and ${ }^{26} \mathrm{Al}$ are directly related to denudation rate, allowing quantification on long-term timescales (Gosse and Phillips 2001). Initial application of cosmogenic nuclides to denudation rate determination was limited to areas of widely distributed, exposed rock, often at high latitudes or in arid environments (e.g., Nishiizumi et al. 1986; Cockburn et al. 1999). Later work employed these methods in more humid regions, where soil covers much of the land surface (e.g., Heimsath et al. 2001a).

There are two common methods for determining denudation rates using in situ cosmogenic nuclides in humid regions. One relies on fluvial sediments to obtain basin-scale averaged rates (Brown et al. 1995; Bierman and Steig 1996; Granger et al. 1996), and the other uses depth profiles obtained from topographic highs to determine site-specific rates (Siame et al. 2004; Matsushi et al. 2006). Combination of these two methods has the 
potential for providing greater insight into the complex surface processes and landscape development in any particular region (Brown et al. 1995). In this study, we present a direct comparison between denudation rates determined from these two methods in the same lithological region, where the entire study area is characterized by well-developed saprolite.

The regional topographic relief increases if denudation rates on topographic highs are less than basin-scale averaged rates. In contrast, a reduction in relief occurs if the rates on topographic highs exceed basin-scale rates. Comparison of denudation rates from soil-mantled upland obtained from single samples, rather than a depth profile, with basin-scale averaged rates has been previously performed in the Oregon Coast Range (Heimsath et al. 2001a), Australian southeastern highlands (Heimsath et al. 2001b, 2006), and German Black Forest (Meyer et al. 2010). Comparison between summit bedrock and basinaveraged denudation rates has also been performed in the Negev Desert (Clapp et al. 2000), southern Africa (Bierman and Caffee 2001), and the Appalachians (Hancock and Kirwan 2007; Portenga et al. 2013). The advantage of a depth profile of in situ cosmogenic nuclides is that it has the potential to provide information about equilibrium conditions, which cannot be obtained from a single sample.

\section{Denudation rates from in situ cosmogenic nuclides}

Measuring in situ cosmogenic nuclides in river-born sediments allows investigation of denudation rates on drainage basin scales (Brown et al. 1995; Bierman and Steig 1996; Granger et al. 1996; Riebe et al. 2000; Moon et al. 2011; Siame et al. 2011). If exposure to cosmic rays is sufficiently long with respect to the denudation rate, the accumulation of in situ-produced ${ }^{10} \mathrm{Be}$ and

${ }^{26} \mathrm{Al}$ reaches a secular equilibrium, providing information on the maximum denudation rate (Lal 1991). Because rivers carry and mix the sediment produced within a given drainage basin, denudation rates deduced from river-born quartz were identified as ideal material for quantifying denudation rates of an entire watershed (Brown et al. 1995; Bierman and Steig 1996; Granger et al. 1996).

Although the principle is simple, the culmination of a series of assumptions and approximations may compound some uncertainty. Stream sediment is not always representative of the entire watershed, especially within smaller watersheds prone to episodic mass wasting (Niemi et al. 2005; Granger and Riebe 2007). Storage and burial of river sediments would also disturb the initial concentration of cosmogenic nuclides by radioactive decay, which creates a case where the measured nuclide concentration underestimates the steady-state nuclide concentration (Wittmann et al. 2011). This methodology has been tested for small (1 to $10 \mathrm{~km}^{2}$; Granger et al. 1996) and large $\left(10^{2}\right.$ to $10^{5} \mathrm{~km}^{2}$; Schaller et al. 2001) drainage basins, as well as in different geologic and climatic settings (Portenga and Bierman 2011 and references therein). Many regional-scale cosmogenic studies indicate that environmental parameters, such as precipitation, temperature, altitude, basin slope, and tectonics, can influence denudation rates (Riebe et al. 2000; von Blanckenburg 2005; Henck et al. 2011; Moon et al. 2011, Siame et al. 2011). However, quantitative assessment of the contributions from independent environmental parameters is still under debate, due in part to the lack of direct comparison between basin scale and site-specific denudation rates.

Depth profiles of in situ cosmogenic nuclides allow determination of site-specific denudation rates in humid regions without the complex assumptions required for basin-scale studies (Siame et al. 2004; Matsushi et al. 2006). Topographic highs such as mountain summits, hilltops, and ridges are appropriate sites for depth profiling due to the minimized influence of along-slope mass transport (Shiroya et al. 2010). Another advantage stemming from the usage of depth profiles is that information regarding nuclide equilibrium is also obtained (see the following). Cumulative concentration of a particular nuclide at an outcrop is a function of the denudation rate $(D)$ and exposure age $(T)$, so that measurement of one nuclide (typically ${ }^{10} \mathrm{Be}$ ) at the surface cannot uniquely identify $D$ and $T$. The use of depth profiles has recently been introduced to alleviate this problem (Siame et al. 2004; Braucher et al. 2009). Depth profiles have been used to determine the ages of fluvial terraces (Hein et al. 2009; Hidy et al. 2010; Rixhon et al. 2011).

In this study, we present denudation rates for a granitic saprolite in the Abukuma Mountains, Japan, using in situ cosmogenic nuclides measured in both depth profile and fluvial sediments. A known saprolite density is required to determine the denudation rate using cosmogenic nuclides. However, previous studies have often treated density as a free parameter (Siame et al. 2004; Rixhon et al. 2011). Therefore, we also conduct actual field measurements of the saprolite density. Together with ${ }^{26} \mathrm{Al} /{ }^{10} \mathrm{Be}$ plots of fluvial sediment, these data indicate that there are distinct variations in denudation rates obtained from the topographic highs and from basinscale approaches.

\section{Study area and sampling strategy}

The Abukuma Mountains, a major granitic terrain in Japan, formed as an uplifted peneplain (e.g., Koike 1968) (Figure 1). The mountains consist of low-relief hills of granitic saprolite at an elevation of 400 to $600 \mathrm{~m}$ above sea level covered by soil and vegetation. Freshly exposed bedrock and gully development are not observed. Because the mountains are not steep, landslides are also 

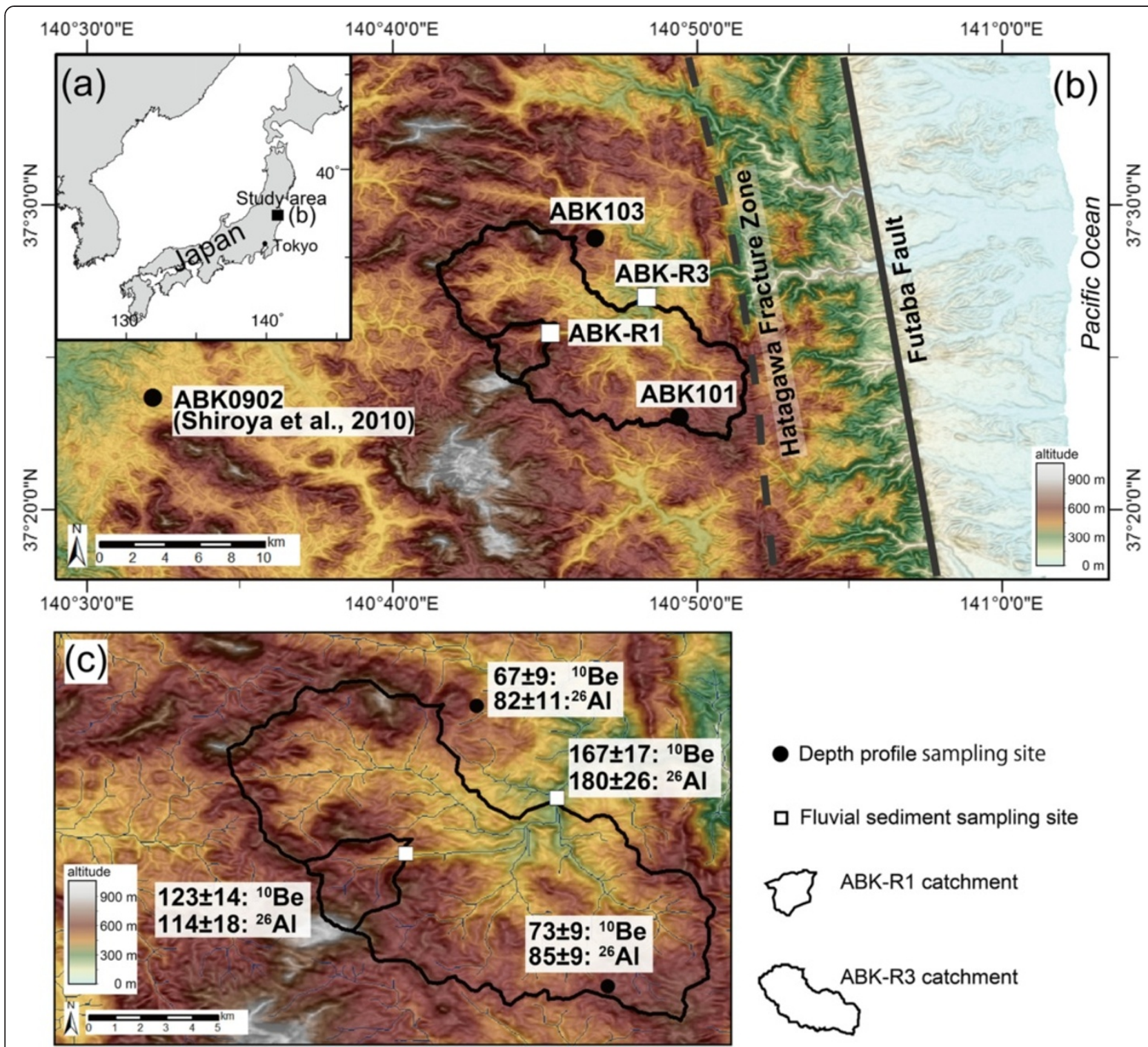

Figure 1 The Abukuma Mountains, a major granitic terrain in Japan, formed as an uplifted peneplain. (a) Location of the study area. (b) Digital elevation map of the sampling sites. (c) Close-up of the catchments. Elevation data is obtained from ASTER GDEM (http://gdem.ersdac. jspacesystems.or.jp/). Black dots indicate the sampling sites for depth profiles. Open squares indicate the sampling sites for fluvial sediments. Catchments of the sites are also indicated as solid lines. Numbers described are denudation rates $(\mathrm{mm} / \mathrm{kyr})$ obtained from this study.

not reported in this region (Shimizu and Oyagi 1988). The Abukuma granitic terrain is petrologically separated by the N-S trending Hatagawa fracture zone and the Futaba fault (Figure 1). Recent activity of a west-dipping reverse fault with a dip slip rate of 50 to $100 \mathrm{~mm} / \mathrm{kyr}$ has been reported for Futaba fault (Fukushimaken 1999). Annual mean precipitation is $1,465 \mathrm{~mm}$ with a peak in September, and annual mean temperature is $10.3^{\circ} \mathrm{C}$ (calculated from 1981 to 2010 at Kawauchi, Japan; http:// www.jma.go.jp/jma/indexe.html).

Depth profile sampling sites, ABK101 (N 37.384, E 140.824) and ABK103 (N 37.482, E 140.778), are roadside outcrops covered by approximately $20 \mathrm{~cm}$ of black soil and are located near the topographic highs in the eastern part of the Abukuma Mountains at an altitude of 620 and $540 \mathrm{~m}$, respectively (Figures 1 and 2, Table 1 ). These are rounded, gently sloping, and deeply weathered $(>3 \mathrm{~m}$ deep), which indicates no significant influence from catastrophic mass wasting. The saprolite exhibits original granitic textures, also indicating that no significant disturbance or mixing has occurred during in situ weathering. The entire study area is characterized by soil of relatively uniform thickness that is underlain by well-developed saprolite to appreciable depth. Samples for cosmogenic 


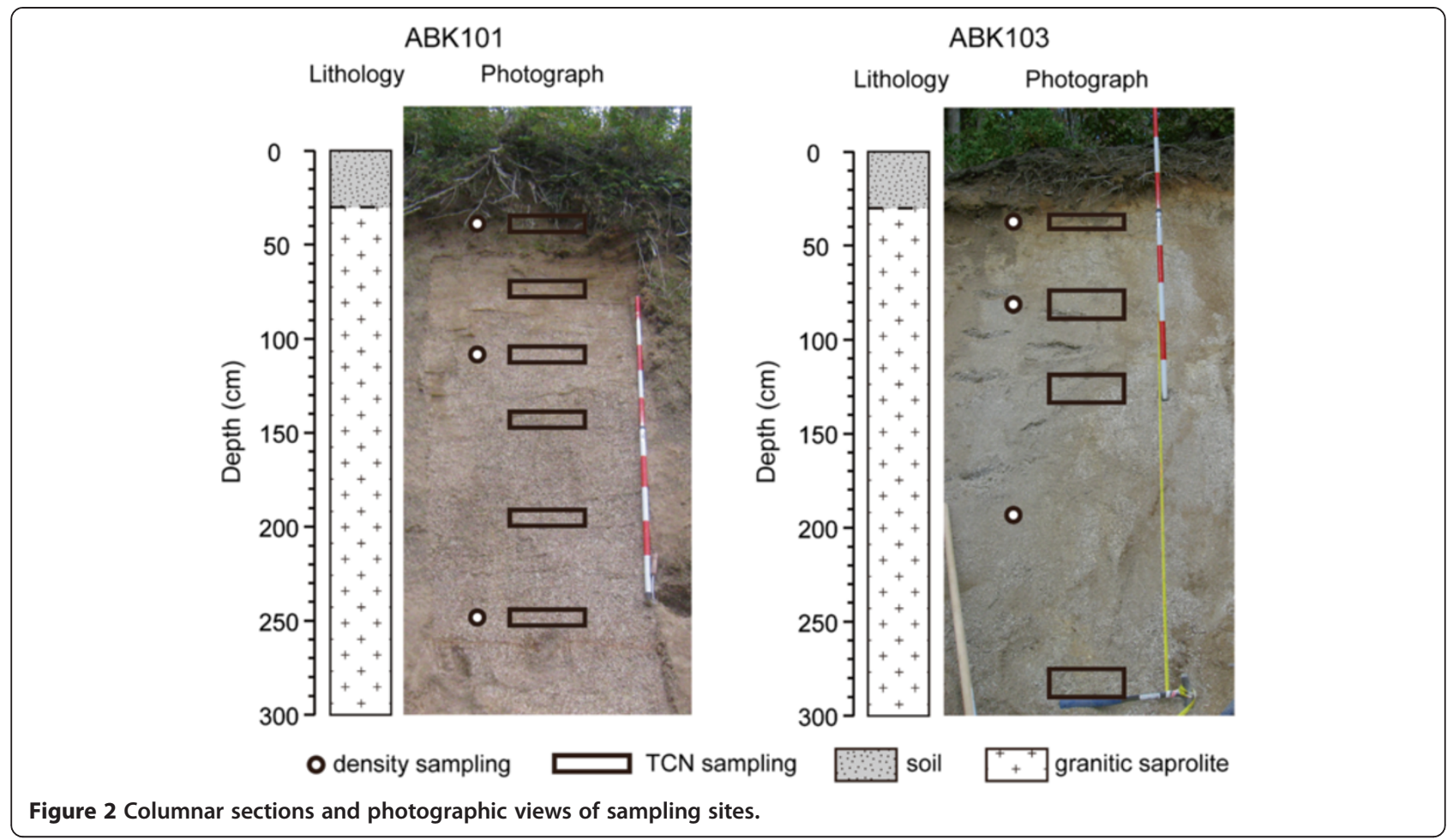

nuclide measurement were collected from below the soil horizon. Plastic tubes $(5 \mathrm{~cm}$ long) were placed into the granitic saprolite to determine its wet and dry density (Figure 3). Here, we use mean wet bulk density at the sampling site for calculation because granitic saprolite contains water, in contrast to fresh rock. ABK-R1 (N 37.431, $\mathrm{E}$ 140.754) and ABK-R3 (N 37.450, E 140.807) are the fluvial sites, located in the Takase River (Figure 1, Table 1). The catchment areas of the fluvial sampling sites are between ABK101 and ABK103 and do not include the Hatagawa fracture zone.

\section{Methods}

Samples for depth profiles were crushed to a grain size of 0.35 to $1 \mathrm{~mm}$, and quartz grains were subsequently separated by chemical etching following the method of Kohl and Nishiizumi (1992). River sediments were sieved to 0.35 to $1 \mathrm{~mm}$ size fractions for analysis. The purified quartz samples (approximately $25 \mathrm{~g}$ ) were dissolved with $\mathrm{HF}$ and spiked with Be carrier (approximately $0.3 \mathrm{mg}$ ). Aliquots for Be and $\mathrm{Al}$ were separated by column chromatography and then oxidized for accelerator mass spectrometry (AMS) measurements at the University of Tokyo. The standards used were 07KNSTD (KNB5-1) for ${ }^{10} \mathrm{Be}$ $\left({ }^{10} \mathrm{Be} /{ }^{9} \mathrm{Be}\right.$ ratio $2.709 \times 10^{-11}$; Nishiizumi et al. 2007) and KNSTD (KNA4-2) for ${ }^{26} \mathrm{Al}\left({ }^{26} \mathrm{Al} /{ }^{27} \mathrm{Al}\right.$ ratio $3.029 \times 10^{-11}$; Nishiizumi 2004). The decrease in cosmogenic nuclide concentrations with depth has previously been modeled using a chi-square $\left(\chi^{2}\right)$ inversion method (Siame et al. 2004; Braucher et al. 2009). For a surface experiencing

Table 1 Site parameters and geometric properties of the drainage basins sampled for cosmogenic measurements

\begin{tabular}{|c|c|c|c|c|c|c|c|c|c|c|c|}
\hline \multirow[t]{2}{*}{ Site } & \multicolumn{3}{|c|}{${ }^{10}$ Be production rate (atoms/g/yr) } & \multicolumn{3}{|c|}{${ }^{26} \mathrm{Al}$ production rate (atoms/g/yr) } & \multirow{2}{*}{$\begin{array}{l}\text { Latitude } \\
{ }^{\circ} \mathrm{N}\end{array}$} & \multirow{2}{*}{$\begin{array}{c}\text { Longitude } \\
{ }^{\circ} \mathrm{E}\end{array}$} & \multirow{2}{*}{$\begin{array}{l}\text { Altitude } \\
(\mathrm{m})\end{array}$} & \multirow{2}{*}{$\begin{array}{l}\text { Mean basin } \\
\text { altitude }(m)^{c}\end{array}$} & \multirow{2}{*}{$\begin{array}{l}\text { Mean slope } \\
\text { (deg) }\end{array}$} \\
\hline & Spallation $^{\mathrm{a}}$ & $\begin{array}{c}\text { Slow } \\
\text { muon }^{\text {b }}\end{array}$ & $\begin{array}{c}\text { Fast } \\
\text { muon }^{b}\end{array}$ & Spallation $^{a}$ & $\begin{array}{c}\text { Slow } \\
\text { muon }\end{array}$ & $\begin{array}{c}\text { Fast } \\
\text { muon }^{b}\end{array}$ & & & & & \\
\hline ABK101 & 6.90 & 0.016 & 0.045 & 46.64 & 1.1 & 0.093 & 37.384 & 140.824 & 620 & - & - \\
\hline ABK103 & 6.49 & 0.015 & 0.044 & 43.82 & 1.1 & 0.092 & 37.482 & 140.778 & 540 & - & - \\
\hline ABK-R1 & 7.07 & 0.016 & 0.045 & 47.77 & 1.1 & 0.094 & 37.431 & 140.754 & 463 & 649 & 13.9 \\
\hline ABK-R3 & 6.58 & 0.015 & 0.044 & 44.43 & 1.1 & 0.092 & 37.450 & 140.807 & 339 & 551 & 12.0 \\
\hline
\end{tabular}

a Production rates by high-energy spallation are calculated following Stone (2000) for altitudinal and latitudinal scaling. This is the most commonly used scaling scheme in the existing literature. The scaling factor is a function of atmospheric pressure and geographic latitude; ${ }^{\mathrm{b}}$ production rates by slow and fast muons are calculated according to Braucher et al. (2011); ' mean altitudes of the catchments are calculated by ArcGIS for production rates of fluvial sediments. 


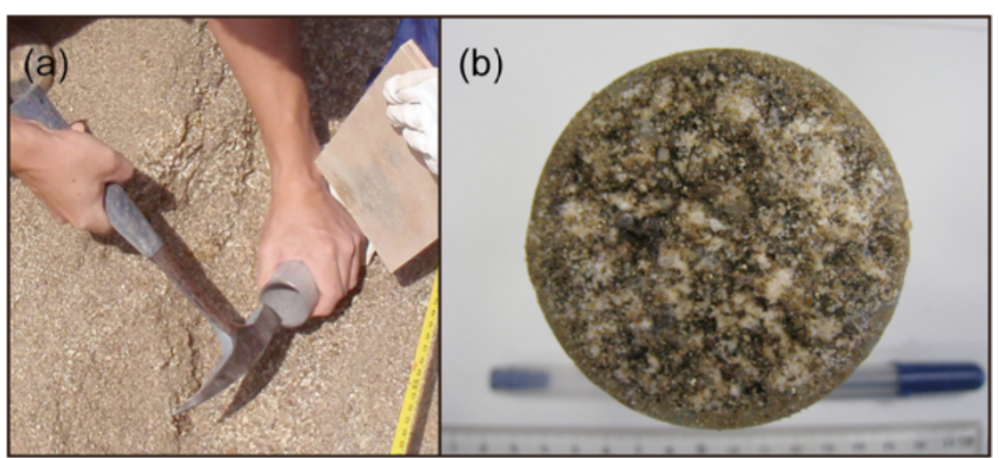

Figure 3 The sampled saprolite. (a) Plastic tubes were placed into the granitic saprolite. (b) The sampled saprolite shows the original granite textures, indicating that no disturbance occurred during sampling.

denudation at rate $\varepsilon(\mathrm{cm} /$ year) during a time interval $d t$, the concentration of cosmogenic nuclides $C$ (atoms/g) with time $t$ (year), and depth $x(\mathrm{~cm})$ is described as

$$
\frac{\partial C}{\partial t}=P_{0} e^{\frac{-\rho x}{\Lambda}}+\varepsilon \frac{\partial C}{\partial x}-C \lambda
$$

where $P_{0}$ (atoms/g/year) is the surface production rate, $\Lambda\left(\mathrm{g} / \mathrm{cm}^{2}\right)$ is the attenuation length, $\rho\left(\mathrm{g} / \mathrm{cm}^{3}\right)$ is the density, and $\lambda$ is the radioactive decay constant $\left(\right.$ year $^{-1}$ ) for ${ }^{10} \mathrm{Be}\left(5.10 \times 10^{-7}\right)$ (Nishiizumi et al. 2007) and ${ }^{26} \mathrm{Al}$ $\left(9.83 \times 10^{-7}\right)($ Nishiizumi 2004). Considering the three reaction mechanisms (neutrons, stopping, and fast muons) and assuming constant rates of denudation, Equation 1 is solved as follows using the initial condition at time $t=0$ that $C=0$.

$$
\begin{aligned}
C(x, t)= & \frac{P_{\text {spal }}}{\frac{\rho \varepsilon}{\Lambda_{\text {spal }}}+\lambda} e^{\frac{-\rho x}{\Lambda_{\text {spal }}}}\left(1-e^{-\left(\lambda+\frac{\rho \varepsilon}{\Lambda_{\text {spal }}}\right) t}\right) \\
& +\frac{P_{\text {stop }}}{\frac{\rho \varepsilon}{\Lambda_{\text {stop }}}+\lambda} e^{\frac{-\rho x}{\Lambda_{\text {stop }}}}\left(1-e^{-\left(\lambda+\frac{\rho \varepsilon}{\Lambda_{\text {stop }}}\right) t}\right) \\
& +\frac{P_{\text {fast }}}{\frac{\rho \varepsilon}{\Lambda_{\text {fast }}}+\lambda} e^{\frac{-\rho x}{\Lambda_{\text {fast }}}}\left(1-e^{-\left(\lambda+\frac{\rho \varepsilon}{\Lambda_{\text {fast }}}\right) t}\right)
\end{aligned}
$$

Here, $P_{\text {spal }}, P_{\text {stop }}$, and $P_{\text {fast }}$ are surface production rates for the three production mechanisms, and $\Lambda_{\text {spal }}, \Lambda_{\text {stop }}$, and $\Lambda_{\text {fast }}$ are the effective attenuation lengths, respectively, of those three rates. Production rates for neutrons are scaled using the method of Stone (2000) based on the reference ${ }^{10} \mathrm{Be}$ production rate of 4.49 (atoms/g/year) with ${ }^{26} \mathrm{Al} /{ }^{10} \mathrm{Be}=6.75$ (Balco et al. 2008). Production rates for muons are calculated following Braucher et al. (2011). This study uses the values: $\Lambda_{\text {spal }}=160\left(\mathrm{~g} / \mathrm{cm}^{2}\right)$, (Lal 1991; Brown et al., 1995), $\Lambda_{\text {stop }}=1,500\left(\mathrm{~g} / \mathrm{cm}^{2}\right)$, $\Lambda_{\text {fast }}=4,320\left(\mathrm{~g} / \mathrm{cm}^{2}\right)$ (Heisinger et al. 2002a, b; Braucher et al. 2011).
The $\chi^{2}$ inversion model (Siame et al. 2004) for best fitting of the model is as follows:

$$
\chi^{2}=\sum_{i=1}^{N}\left(\frac{C_{i}-C\left(x_{i}, \varepsilon, t\right)}{\sigma_{i}}\right)^{2}
$$

Here, $C_{i}$ and $\sigma_{i}$ are the measured cosmogenic nuclide concentration and its standard deviation at the depth $x_{i}$, respectively, and $C\left(x_{i}, \varepsilon, t\right)$ is the theoretical concentration computed using Equation 3 with a given timedenudation $(\varepsilon, t)$ pair. A nuclide concentration at a variety of depths below the surface can provide both $D$ and $T$ information. Not only does this approach allow determination of ages (Hein et al. 2009; Hidy et al. 2010; Rixhon et al. 2011) but also allows testing of the equilibrium condition. On topographic highs, where cosmic ray exposure is infinitely long, exposure time calculated by the $x^{2}$ method is expected to indicate equilibrium. If mass movement has significantly influenced the outcrop, $\chi^{2}$ inversion would exhibit lower, nonequilibrium values. Therefore, this method is useful for confirming the existence of the equilibrium condition, which is required to accurately calculate denudation rates. Uncertainties of denudation rates include both uncertainty of density and uncertainty of $X^{2}$ inversion, determined as $\chi^{2} \leq \chi_{\min }^{2}+1$ following the method of Rixhon et al. (2011).

Basin-scale denudation rates from river-born quartz are also determined following the method of Granger et al. (1996), where the terms are the same as those listed previously.

$$
\varepsilon=\frac{P_{\text {spal }} \Lambda_{\text {spal }}+P_{\text {stop }} \Lambda_{\text {stop }}+P_{\text {fast }} \Lambda_{\text {fast }}}{C \rho}
$$

Mean altitudes of the catchments calculated by ArcGIS with ASTER GDEM elevation data (http://www. gdem.aster.ersdac.or.jp/) are used for production rates of fluvial sediments (Table 1). The effects of topographic shielding are insignificant and therefore not included 
because the production rate is not affected by the lowrelief geometry of the study area.

\section{Results}

$x^{2}$ fitting for the depth profiles

Measured wet bulk densities ranged between 1.59 and $1.68 \mathrm{~g} / \mathrm{cm}^{3}$ with no systematic depth trend (Figure 4, Table 2). Similar stability of the dry bulk density indicates constant water content. Therefore, we used the average wet bulk density of each sampling site for calculation of cosmogenic nuclide depth profiles. The values are $1.66 \pm 0.07$ and $1.61 \pm 0.07 \mathrm{~g} / \mathrm{cm}^{3}$ for sites ABK101 and ABK103, respectively.

Figure 5 shows that measured ${ }^{10} \mathrm{Be}$ and ${ }^{26} \mathrm{Al}$ concentrations decrease exponentially with depth (Table 3). Low $\chi^{2}$ values are distributed parallel to the axes of exposure age (Figure 6). Therefore, $\chi^{2}$ fitting indicates that steady-state concentrations have been reached. Denudation rates at site ABK101 are $73 \pm 9$ and $85 \pm 9 \mathrm{~mm} / \mathrm{kyr}$ for ${ }^{10} \mathrm{Be}$ and ${ }^{26} \mathrm{Al}$, respectively, whereas $67 \pm 9$ and $82 \pm 11 \mathrm{~mm} / \mathrm{kyr}$ were measured for ${ }^{10} \mathrm{Be}$ and ${ }^{26} \mathrm{Al}$, respectively, at site ABK103 (Figures 5 and 6). The uncertainty reflects uncertainties in both measurements of density and $\chi^{2}$ inversion. Although the modeled curves are not perfectly fit to the measured concentration, two independent lines of evidence indicate that the derived denudation rates are reliable. First, rates calculated from both ${ }^{10} \mathrm{Be}$ and ${ }^{26} \mathrm{Al}$ are consistent, and second, both sampling sites exhibit almost identical denudation rates. Thus, we interpret that the cosmogenic nuclides data accurately represent local denudation rates. It should be noted that relatively large $\chi^{2}$ values are observed for ${ }^{10} \mathrm{Be}$ profiles compared with ${ }^{26} \mathrm{Al}$ profiles at site ABK103 (Figure 6). This might due to
Table 2 Summary of density measurements

\begin{tabular}{cccccc}
\hline Sample & $\begin{array}{c}\text { Depth } \\
(\mathbf{m})\end{array}$ & $\begin{array}{c}\text { Wet density } \\
\left(\mathbf{g} / \mathbf{c m}^{3}\right)\end{array}$ & $\mathbf{1} \boldsymbol{\sigma}$ error & $\begin{array}{c}\text { Dry density } \\
\left(\mathbf{g} / \mathbf{c m}^{\mathbf{3}}\right)\end{array}$ & $\mathbf{1} \boldsymbol{\sigma}$ error \\
\hline ABK101-8d & 39.0 & 1.64 & 0.07 & 1.41 & 0.06 \\
ABK101-12d & 108.3 & 1.68 & 0.07 & 1.47 & 0.06 \\
ABK101-20d & 248.5 & 1.65 & 0.07 & 1.43 & 0.06 \\
ABK103-1d & 37.2 & 1.59 & 0.07 & 1.43 & 0.06 \\
ABK103-3d & 81.7 & 1.61 & 0.07 & 1.45 & 0.06 \\
ABK103-8d & 193.2 & 1.62 & 0.07 & 1.45 & 0.06 \\
\hline
\end{tabular}

relatively high ${ }^{10} \mathrm{Be} /{ }^{9} \mathrm{Be}$ ratios for the process blanks (Table 3) compared with those used in recent publications (e.g., Larsen et al. 2014).

\section{Denudation rates from fluvial sediments}

Basin-scale denudation rates are calculated from the concentration of cosmogenic nuclides using Equation 4. For river sediments, we used $1.63 \pm 0.07 \mathrm{~g} / \mathrm{cm}^{3}$ as the density of the basin, which is the average value of sites ABK101 and ABK103. This assumption is justified because these two values are consistent within their uncertainties. Furthermore, well-developed saprolite is widespread and representative at the scale of the entire catchment, which allows us to calculate the denudation rates for the basins using the measured density at the sites of the depth profiles. The catchment-averaged denudation rate of site ABK-R1 is $123 \pm 14$ and $114 \pm 18 \mathrm{~mm} / \mathrm{kyr}$, as obtained from ${ }^{10} \mathrm{Be}$ and ${ }^{26} \mathrm{Al}$, respectively. ABK-R3 exhibits rates of $167 \pm 17$ and $180 \pm 26 \mathrm{~mm} / \mathrm{kyr}$ from ${ }^{10} \mathrm{Be}$ and ${ }^{26} \mathrm{Al}$, respectively. In most previous studies, only a single nuclide, typically ${ }^{10} \mathrm{Be}$, is measured for determination

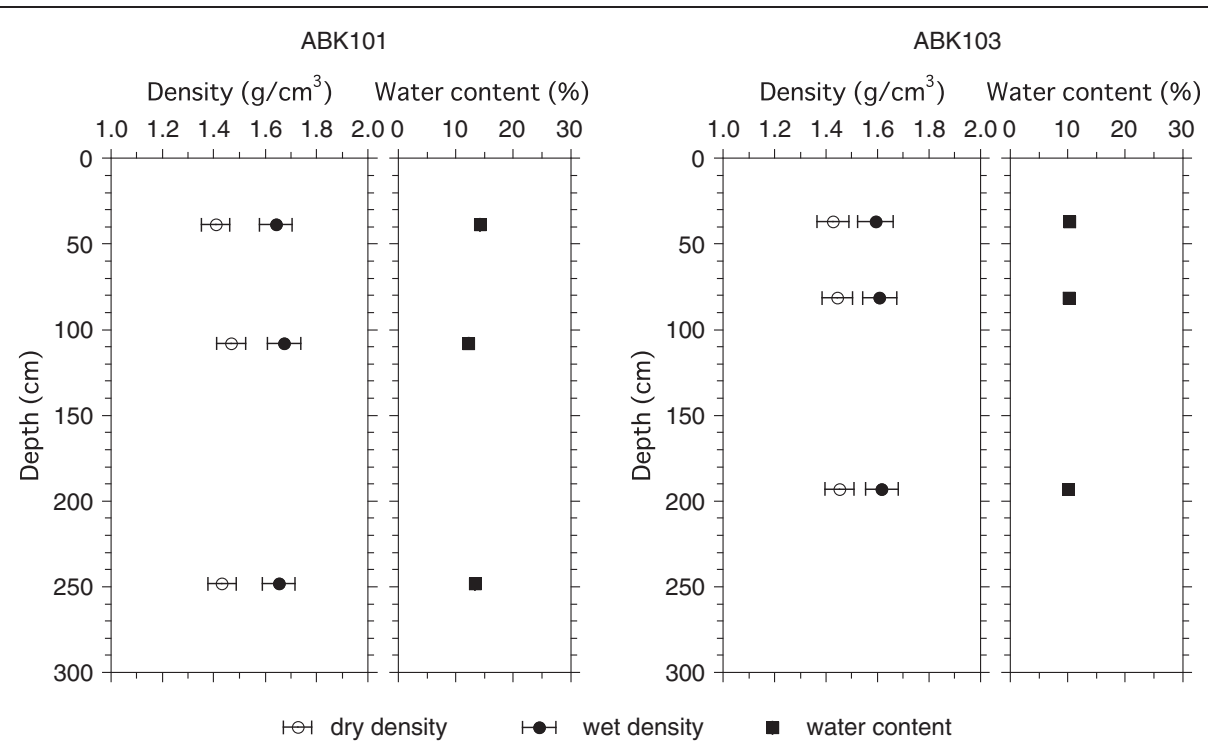

Figure 4 Dry density (open circles), wet density (filled circles), and water content (squares) of the samples. 

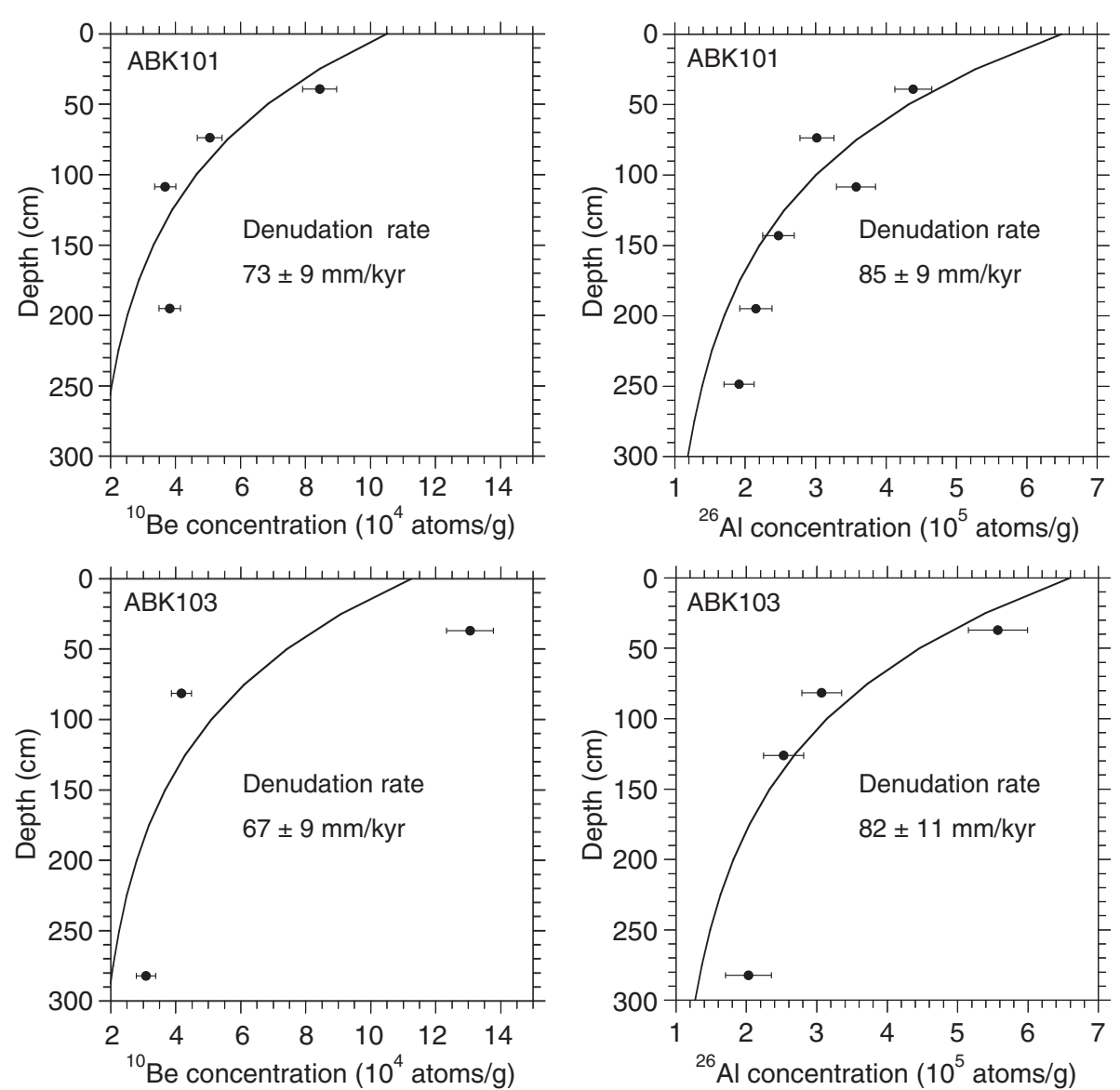

Figure 5 Depth profile of cosmogenic nuclides (circles) with model-best-fit (curve) concentrations based on steady denudation (Equation 2). Error bars show analytical uncertainties (10).

Table 3 Summary of sample data from the Abukuma Mountains

\begin{tabular}{|c|c|c|c|c|c|c|c|c|c|c|}
\hline Sample & $\begin{array}{c}\text { Depth } \\
\text { (cm) }\end{array}$ & $\begin{array}{c}\text { Dissolved } \\
\text { quartz (mg) }\end{array}$ & $\begin{array}{c}{ }^{10} \mathrm{Be} /{ }^{9} \mathrm{Be} \\
\left(10^{-14}\right)\end{array}$ & $\begin{array}{l}1 \sigma \text { error } \\
\left(10^{-14}\right)\end{array}$ & $\begin{array}{c}{ }^{10} \text { Be concentration } \\
\left(10^{4} \text { atoms } / g\right)\end{array}$ & $\begin{array}{c}1 \sigma \text { error } \\
\left(10^{4} \text { atoms } / g\right)\end{array}$ & $\begin{array}{c}{ }^{26} \mathrm{Al} /{ }^{27} \mathrm{Al} \\
\left(10^{-13}\right)\end{array}$ & $\begin{array}{l}1 \sigma \text { error } \\
\left(10^{-13}\right)\end{array}$ & $\begin{array}{c}{ }^{26} \mathrm{Al} \text { concentration } \\
\left(10^{5} \text { atoms } / \mathrm{g}\right)\end{array}$ & $\begin{array}{c}1 \sigma \text { error } \\
\left(10^{5} \text { atoms } / g\right)\end{array}$ \\
\hline ABK101-8 & 39.0 & $25,028.70$ & 10.63 & 0.66 & 8.43 & 0.53 & 2.37 & 0.14 & 4.38 & 0.26 \\
\hline ABK101-10 & 73.6 & $25,020.16$ & 6.35 & 0.48 & 5.05 & 0.38 & 1.73 & 0.14 & 3.02 & 0.24 \\
\hline ABK101-12 & 108.3 & $24,973.98$ & 4.59 & 0.41 & 3.68 & 0.33 & 1.70 & 0.13 & 3.57 & 0.28 \\
\hline ABK101-14 & 142.9 & $25,009.59$ & - & - & - & - & 1.32 & 0.12 & 2.47 & 0.23 \\
\hline ABK101-17 & 194.9 & $25,012.77$ & 4.81 & 0.41 & 3.82 & 0.33 & 1.09 & 0.12 & 2.15 & 0.23 \\
\hline ABK101-20 & 248.5 & $24,978.36$ & - & - & - & - & 0.99 & 0.11 & 1.91 & 0.21 \\
\hline ABK103-1 & 37.2 & $25,007.06$ & 16.63 & 0.92 & 13.05 & 0.72 & 2.40 & 0.18 & 5.57 & 0.42 \\
\hline ABK103-3 & 81.7 & $25,003.43$ & 5.24 & 0.39 & 4.17 & 0.31 & 1.34 & 0.12 & 3.07 & 0.28 \\
\hline ABK103-5 & 126.3 & $24,997.33$ & - & - & - & - & 1.29 & 0.15 & 2.53 & 0.29 \\
\hline ABK103-12 & 282.4 & $22,166.50$ & 3.44 & 0.33 & 3.08 & 0.29 & 0.87 & 0.14 & 2.03 & 0.33 \\
\hline ABK-R1 & - & $29,839.39$ & 10.42 & 0.53 & 6.96 & 0.36 & 2.98 & 0.30 & 5.29 & 0.52 \\
\hline ABK-R3 & - & $24,123.85$ & 5.83 & 0.26 & 4.80 & 0.22 & 2.01 & 0.17 & 3.16 & 0.26 \\
\hline
\end{tabular}

Background values of ${ }^{10} \mathrm{Be}$ and ${ }^{26} \mathrm{Al}$ are subtracted using the value of each process blank, which is treated in the same batch. ${ }^{10} \mathrm{Be}$ ratios of process blanks for depth profile and river sediment are $2.63 \pm 0.20 \times 10^{-14}$ and $2.13 \pm 0.12 \times 10^{-14}$, respectively. These values are indistinguishable from the value of ${ }^{10} \mathrm{Be} /{ }^{9} \mathrm{Be}$ of added commercial 100 ppm Be carrier (Wako Co., Ltd.; $2 \times 10^{-14}$ ), and the long-term average value of the process blank $\left(2 \times 10^{-14}\right)$. ${ }^{26} \mathrm{Al}$ ratios of process blanks for depth profile and river sediment are $5.28 \pm 0.74 \times 10^{-15}$ and $7.12 \pm 7.12 \times 10^{-16}$, respectively. Counting errors $(1 \sigma)$ of standards and process blanks measured with AMS are propagated to the counting uncertainty on the sample ratios. We do not have Be data for ABK101-14, -20 , and ABK103-5 because sample treatment was unsuccessful. 

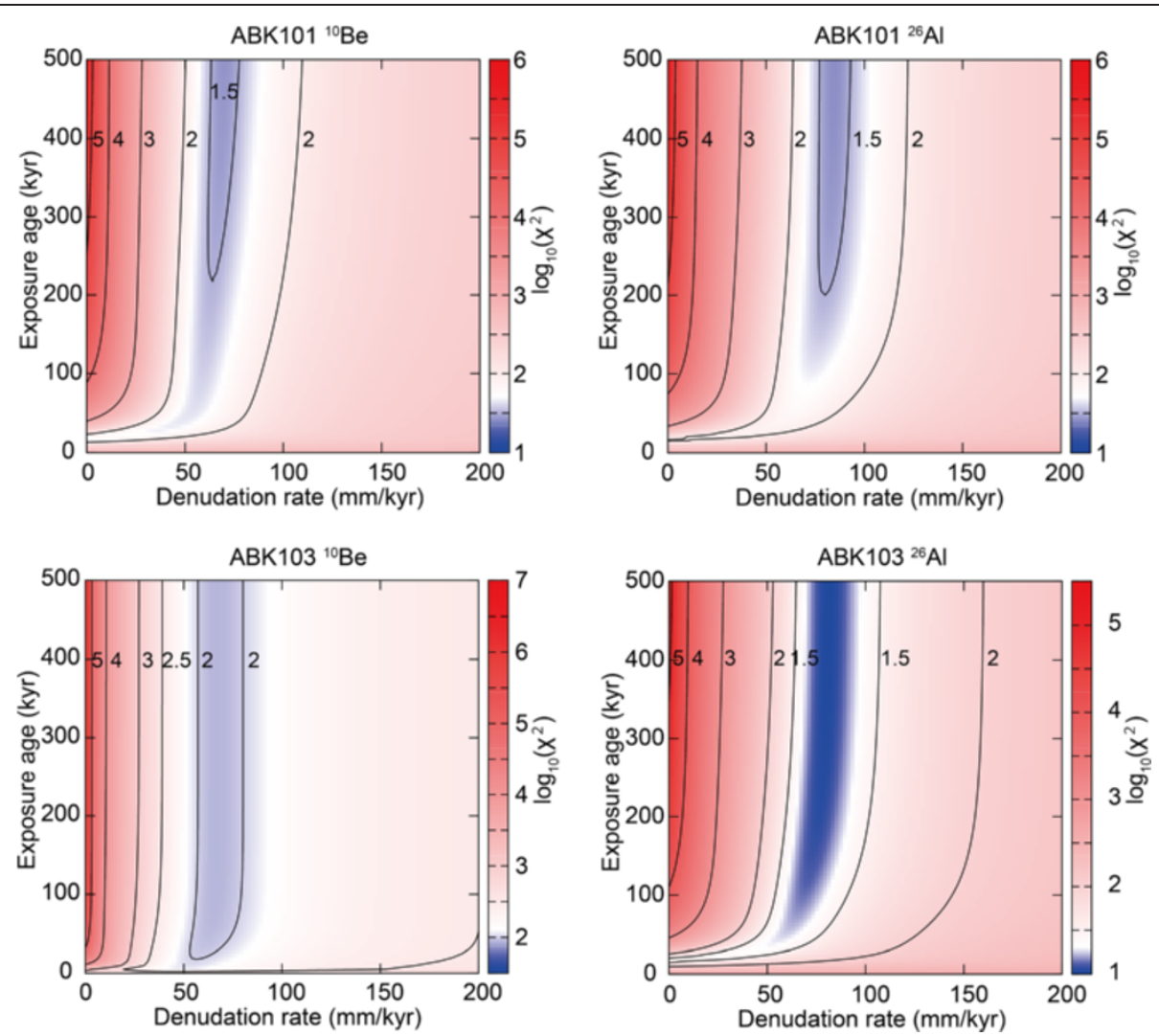

Figure 6 Contour plots of the $\log \left(x^{2}\right)$ based on Equation 2. Blue areas indicate where equilibrium conditions are reasonable.

of catchment-averaged denudation rate. However, denudation rates derived from a single nuclide may be biased by complex exposure histories (Wittmann et al. 2011). In order to test the steady-state denudation model, the data are plotted on an 'erosion-island' graph (Lal 1991) (Figure 7). The plots show close agreement between denudation rates based on ${ }^{10} \mathrm{Be}$ and ${ }^{26} \mathrm{Al}$, within error limits, inside the 'erosion-island' area, supporting that these samples do not record complex exposure histories. Although complex histories of sediment transportation cannot be ruled out completely because of the large uncertainties, the combination of ${ }^{10} \mathrm{Be}$ and ${ }^{26} \mathrm{Al}$ results indicates negligible Myr-scale sediment burial. The large uncertainties are more likely the result of low cosmogenic nuclide concentration, resulting from the fast denudation rate taking place in low elevation area, which leads low nuclide production.

\section{Discussion}

\section{Density dependence of nuclide concentration profiles}

Denudation rates calculated from Equations 2 and 4 are highly sensitive to density variation, with large changes resulting from reasonable density adjustments. For example, substitution of $2.00 \mathrm{~g} / \mathrm{cm}^{3}$ for the measured value

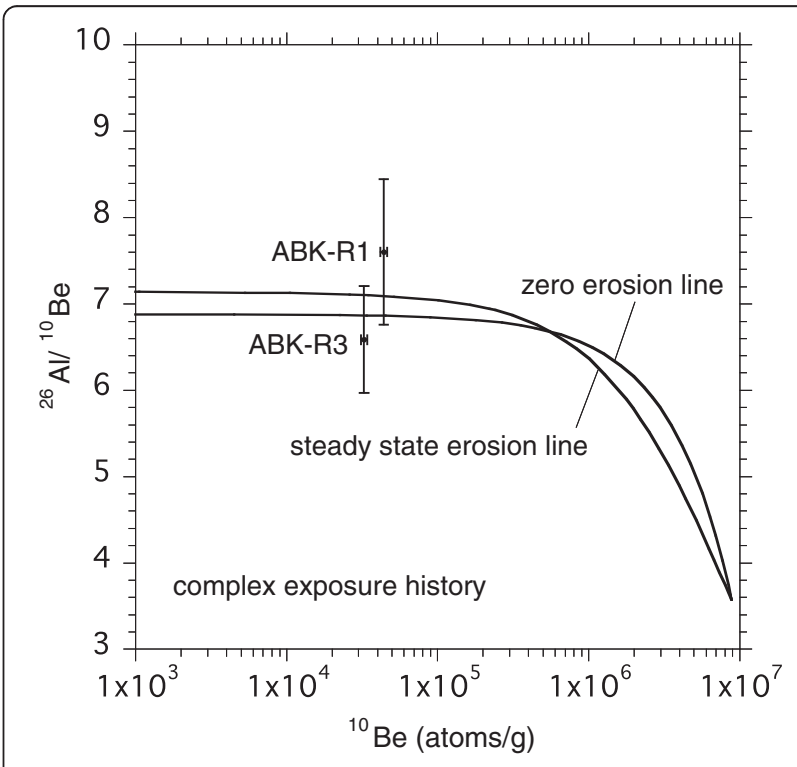

Figure 7 Plot of ${ }^{26} \mathrm{Al} /{ }^{10} \mathrm{Be}$ ratios versus ${ }^{10} \mathrm{Be}$ concentration of fluvial samples with $1 \sigma$ errors. ${ }^{10} \mathrm{Be}$ concentrations are normalized for values at sea level and high latitude. Zero denudation and steady-state denudation lines are shown as solid lines. ${ }^{26} \mathrm{Al} /{ }^{10} \mathrm{Be}$ ratios indicate that these samples do not have complex exposure histories detected by the ${ }^{26} \mathrm{Al} /{ }^{10}$ Be system. 
of $1.66 \mathrm{~g} / \mathrm{cm}^{3}$ changes the ${ }^{10} \mathrm{Be}$ denudation rate of ABK101 from 73 to $54 \mathrm{~mm} / \mathrm{kyr}$, a $25 \%$ change resulting from only a $0.34 \mathrm{~g} / \mathrm{cm}^{3}$ shift in density. This underscores the importance of accurate density measurements, as has been previously reported by several authors.

Braucher et al. (2009) suggested that the density used by Hidy et al. (2005) was too high and advocated consideration of density as a free parameter for denudation and time. Hidy et al. (2010) measured density by inserting a pliable plastic bag into the sampling hole and filling it with a measured quantity of water to determine the volume of the excavated mass of rock. They state that density measured in the field should be considered a maximum value because excavation of a very coarse boulder to gravel-sized fillings may lead to systematic error. They therefore allowed the density to vary randomly using Monte Carlo simulations. Rixhon et al. (2011) treated density as a free parameter, adjusting it within a 1.8 to $2.4 \mathrm{~g} / \mathrm{cm}^{3}$ range.

Although these studies have attempted to identify density variations, accurate measurement of density for terrace sediments is complicated by the presence of boulders. In contrast, we successfully measured density by employing the newly developed technique of using constant volume plastic tubes for granitic saprolite. Time-dependent variation in density (Rodés et al. 2011) is negligible in the study area because of the homogeneous distribution of granitic saprolite with little differential weathering. Measured density exhibits a constant value with depth, indicating that chemical weathering gradients are not significant for the time scale of interest. In addition, granitic saprolite is widely and homogenously distributed at scales larger than outcrop size (>3 $\mathrm{m}$ deep, >10 $\mathrm{m}$ wide). Therefore, denudation rates determined in our study are indicative of those following saprolite formation. Note that the density of soil above the saprolite was not measured because plant roots blocked the sampling tube. Nevertheless, density of soil does not affect our interpretation because its thickness is only $20 \mathrm{~cm}$ and its density, typically regarded as 1.4$1.8 \mathrm{~g} / \mathrm{cm}^{3}$ (Siame et al. 2011; Heimsath et al. 2012), is indistinguishable from that of the saprolite.

We reanalyzed the denudation rates reported by Shiroya et al. (2010) in the western part of the Abukuma Mountains using actual measured density. They determined denudation rates from the depth profile of a quartz vein in granitic saprolite along a mountain ridge assuming $2.2 \mathrm{~g} / \mathrm{cm}^{3}$ for the density of wet granitic saprolite. The reported denudation rates were $61+6 /-4$ and $62+4 /-3 \mathrm{~mm} / \mathrm{kyr}$ based on ${ }^{10} \mathrm{Be}$ and ${ }^{26} \mathrm{Al}$ depth profiles, respectively. In the current study, we applied the actual density of the rock at this site $\left(1.76 \pm 0.03 \mathrm{~g} / \mathrm{cm}^{3}\right)$ and parameters described in Shiroya et al. (2010) for recalculation, which resulted in rates of $86 \pm 2$ and
$89 \pm 3 \mathrm{~mm} /$ kyr for ${ }^{10} \mathrm{Be}$ and ${ }^{26} \mathrm{Al}$-based determinations, respectively. These values are 1.4 times larger than the initial values reported by Shiroya et al. (2010), indicating that direct density measurements are indeed crucial for determining accurate denudation rates. These reanalyzed values are consistent with values obtained from sites ABK101 and ABK103 in the present study. Hence, the three sampling sites at topographic highs in the Abukuma Mountains show consistent values between 67 and $89 \mathrm{~mm} / \mathrm{kyr}$.

\section{Comparison between depth profile and fluvial methods}

Denudation rates deduced from analyses of fluvial sediments are 1.3 to 2.7 times larger than those determined from depth profiles $(p<0.01)$. Multiple depth profiles of cosmogenic nuclides provide the denudation rate of the summit plane, whereas fluvial sediments represent a basin-scale average. Thus, our measurements show that there are contrasts in denudation rates between topographic highs and the entire basin as a whole, primarily due to differences in surficial gradient. This supports previous studies that found that the slope angle of a basin significantly affects the overall denudation rate (Riebe et al. 2000; von Blanckenburg 2005). However, it should be noted that the mean basin slope is $13.9^{\circ}$ and $12.0^{\circ}$ for ABK-R1 and ABK-R3, respectively (Table 1), indicating that fluvial denudation rates are not sensitive to small differences in slope angles in the study area before the threshold for hill slope stability is reached. The slow upper stream denudation rate is also not attributed to the spatial distribution of the slope angle because the two basins exhibit a similar slope pattern (Figure 8). The

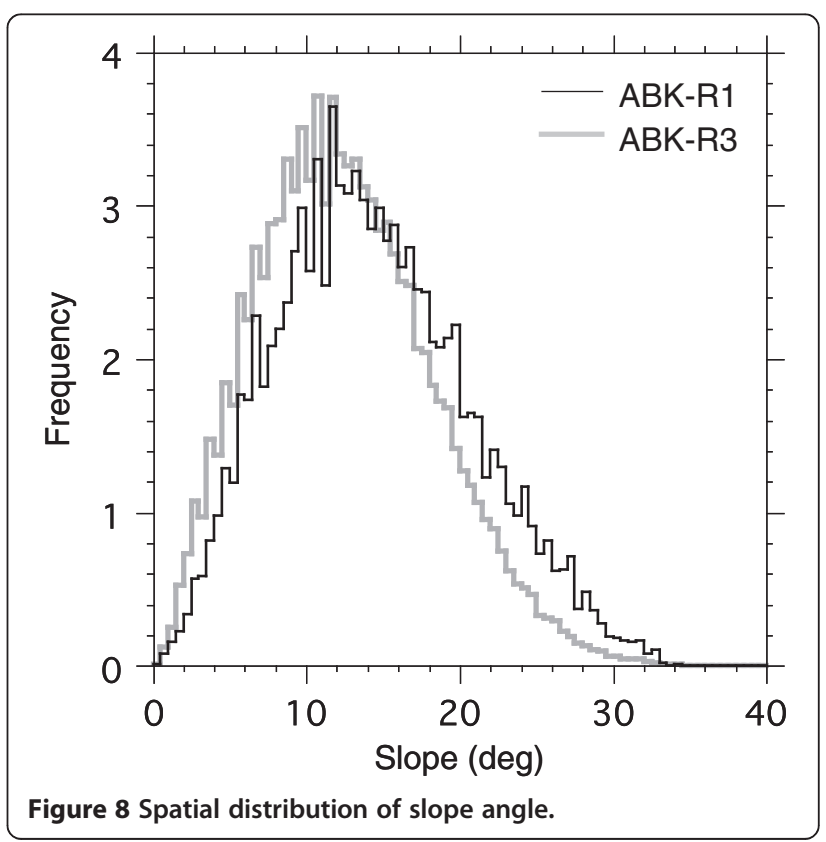


lower basin-scale denudation rate of ABK-R1 compared with ABK-R3 is likely derived from localized low denudation rates due in part to its location proximal to the ridgeline.

Subtraction of the site-specific denudation rate from the basin-scale rate (29 to $113 \mathrm{~mm} / \mathrm{kyr}$ ) represents the rate of change of local topographic relief. Overall, local topographic relief of the Abukuma Mountain is interpreted to be increasing. This is the first comparison of these two methods in the same lithological region in Japan, which allows us to quantitatively investigate regional landscape evolution. Yamamoto (2005) showed that fluvial incision rates, based on tephrostratigraphy, are 80 to $150 \mathrm{~mm} / \mathrm{kyr}$ during the Late Quaternary according to the relative height of fluvial terraces. This is consistent with our results. Comparison between rates derived from depth profiles and those applicable to the entire basin is important for understanding landscape development. This requires careful site selection of topographic highs in order to obtain denudation rates that have minimal potential slope influence.

\section{Conclusions}

We compare denudation rates derived from cosmogenic nuclide data from the Abukuma Mountains between summits and catchments. This is the first comparison of these two methods in the same lithological region, where the entire study area is characterized by well-developed saprolite. Slope angle strongly affects the basin-scale averaged denudation rates by as much as 1.3 to 2.7 times, whereas rates derived from depth profiles at summit sites are unaffected. The importance of physical density measurements, as opposed to modeled values, to obtain accurate denudation rates is demonstrated. Denudation rates of topographic highs inferred from depth profiles of cosmogenic nuclides are 67 to $85 \mathrm{~mm} / \mathrm{kyr}$, whereas basin-scale denudation rates derived from concentration of cosmogenic nuclides in fluvial sediments indicate 114 to $180 \mathrm{~mm} / \mathrm{kyr}$.

\section{Competing interests}

The authors declare that they have no competing financial interests.

\section{Authors' contributions}

AN collected the samples, performed experiments, analyzed data, and wrote the paper. YY designed and directed the project, collected the samples, and contributed in writing the paper. KS and YM collected the samples with AN $\mathrm{HM}$ conducted accelerator mass spectrometry experiments along with AN. All authors participated in the data analysis and interpretation of the results. All authors read and approved the final manuscript.

\section{Acknowledgements}

This work was supported by JSPS NEXT program GR031 and GCOE program We thank Dr. L.L. Siame and an anonymous reviewer for their insightful reviews. We thank A. Suzuki, A. Horio, and S. Ochiai for their assistance and S.P. Obrochta for discussing the manuscript.

\section{Author details}

${ }^{1}$ Atmosphere and Ocean Research Institute, University of Tokyo, 5-1-5 Kashiwanoha, Kashiwa, Chiba 277-8564, Japan. ${ }^{2}$ Department of Earth and Planetary Science, Graduate School of Science, University of Tokyo, 7-3-1 Hongo, Bunkyo-ku, Tokyo 113-0033, Japan. ${ }^{3}$ Institute of Biogeoscience, Japan Agency of Marine Science and Technology (JAMSTEC), 2-15 Natsushima-cho, Yokosuka, Kanagawa 237-0061, Japan. ${ }^{4}$ Geological Survey of Japan, National Institute of Advanced Industrial Science and Technology (AIST), AIST Tsukuba Central 7, 1-1-1 Higashi, Tsukuba 305-8567, Japan. ${ }^{5}$ Department of Nuclear Engineering and Management, The University of Tokyo, Yayoi 2-11-16, Bunkyo-ku, Tokyo 113-0032, Japan.

\section{Received: 6 December 2013 Accepted: 23 April 2014}

Published: 21 May 2014

\section{References}

Balco G, Stone JO, Lifton NA, Dunai TJ (2008) A complete and easily accessible means of calculating surface exposure ages or erosion rates from ${ }^{10} \mathrm{Be}$ and ${ }^{26} \mathrm{Al}$ measurements. Quat Geochronol 3:174-195

Berner RA, Lasaga AC, Garrels RM (1983) The carbonate-silicate geochemical cycle and its effect on atmospheric carbon-dioxide over the past 100 million years. Am J Sci 283:641-683

Bierman PR, Caffee M (2001) Slow rates of rock surface erosion and sediment production across the Namib Desert and escarpment, southern Africa. Am J Sci 301:326-358

Bierman PR, Steig EJ (1996) Estimating rates of denudation using cosmogenic isotope abundances in sediment. Earth Surf Processes Landforms 21:125-139

Braucher R, Del Castillo P, Siame L, Hidy AJ, Bourles DL (2009) Determination of both exposure time and denudation rate from an in situ-produced ${ }^{10} \mathrm{Be}$ depth profile: a mathematical proof of uniqueness. Model sensitivity and applications to natural cases. Quat Geochronol 4:56-67

Braucher R, Merchel S, Borgomano J, Bourles DL (2011) Production of cosmogenic radionuclides at great depth: A multi element approach. Earth Planet Sci Lett 309:1-9

Brown ET, Stallard RF, Larsen MC, Raisbeck GM, Yiou F (1995) Denudation rates determined from the accumulation of in situ-produced ${ }^{10} \mathrm{Be}$ in the Luquillo experimental forest, Puerto-Rico. Earth Planet Sci Lett 129:193-202

Clapp EM, Bierman PR, Schick AP, Lekach J, Enzel Y, Caffee M (2000) Sediment yield exceeds sediment production in arid region drainage basins. Geology 28:995-998

Cockburn HAP, Seidl MA, Summerfield MA (1999) Quantifying denudation rates on inselbergs in the central Namib Desert using in situ-produced cosmogenic ${ }^{10} \mathrm{Be}$ and ${ }^{26} \mathrm{Al}$. Geology 27:399-402

Fukushimaken (1999) Futaba fault survey, earthquake-related basic research grants FY 1998 report. Doc 3826:109, Fukushima

Gosse JC, Phillips FM (2001) Terrestrial in situ cosmogenic nuclides: theory and application. Quat Sci Rev 20:1475-1560

Granger DE, Riebe CS (2007) Cosmogenic nuclides in weathering and erosion. In: Drever II (ed) Surface and Ground Water, Weathering, Denudation and Soils, vol. 5. Treatise on Geochemistry (Holland HG, Turekian KK (exec eds). Elsevier, London, pp 1-43

Granger DE, Kirchner JW, Finkel R (1996) Spatially averaged long-term erosion rates measured from in situ-produced cosmogenic nuclides in alluvial sediment. J Geol 104:249-257

Hancock G, Kirwan M (2007) Summit erosion rates deduced from ${ }^{10}$ Be: implications for relief production in the Central Appalachians. Geology 35:89-92

Heimsath AM, Dietrich WE, Nishiizumi K, Finkel RC (2001a) Stochastic processes of soil production and transport: erosion rates, topographic variation and cosmogenic nuclides in the Oregon Coast Range. Earth Surf Processes Landforms 26:531-552

Heimsath AM, Chappell J, Dietrich WE, Nishiizumi K, Finkel RC (2001b) Late quaternary erosion in southeastern Australia: a field example using cosmogenic nuclides. Quat Int 83-85:169-185

Heimsath AM, Chappell J, Finkel RC, Fifield K, Alimanovic A (2006) Escarpment erosion and landscape evolution in southeastern Australia. Geol Soc Am Spec Pap 398:173-190

Heimsath AM, DiBiase RA, Whipple KX (2012) Soil production limits and the transition to bedrock-dominated landscapes. Nat Geosci 5:210-214

Hein AS, Hulton NRJ, Dunai TJ, Schnabel C, Kaplan MR, Naylor M, Xu S (2009) Middle Pleistocene glaciation in Patagonia dated by cosmogenic-nuclide measurements on outwash gravels. Earth Planet Sci Lett 286:184-197 
Heisinger B, Lal D, Jull AJT, Kubik P, Ivy-Ochs S, Neumaier S, Knie K, Lazarev V, Nolte E (2002a) Production of selected cosmogenic radionuclides by muons 1. Fast muons. Earth Planet Sci Lett 200:345-355

Heisinger B, Lal D, Jull AJT, Kubik P, Ivy-Ochs S, Knie K, Nolte E (2002b) Production of selected cosmogenic radionuclides by muons: 2 . Capture of negative muons. Earth Planet Sci Lett 200:357-369

Henck AC, Huntington KW, Stone JO, Montgomery DR, Hallet B (2011) Spatial controls on erosion in the Three Rivers Region, southeastern Tibet and southwestern China. Earth Planet Sci Lett 303:71-83

Hidy AJ, Pederson JL, Cragun WS, Gosse JC (2005) Cosmogenic ${ }^{10}$ Be exposure dating of Colorado river terraces at Lees Ferry, Arizona. Geol Soc Am Abstr 37-7:296

Hidy AJ, Gosse JC, Pederson JL, Mattern JP, Finkel RC (2010) A geologically constrained Monte Carlo approach to modeling exposure ages from profiles of cosmogenic nuclides: an example from Lees Ferry, Arizona. Geochem Geophys Geosyst 11:Q0AA10, doi:10.1029/2010GC003084

Kohl CP, Nishiizumi K (1992) Chemical isolation of quartz for measurement of in-situ-produced cosmogenic nuclides. Geochim Cosmochim Acta 56:3583-3587

Koike K (1968) Geomorphological development of the northern part of the Abukuma Mountains. Komazawa Geography 4-5:109-126

Lal D (1991) Cosmic ray labeling of erosion surfaces: in situ nuclide production rates and denudation models. Earth Planet Sci Lett 104:424-439

Larsen IJ, Almond PC, Eger A, Stone JO, Montgomery DR, Malcom B (2014) Rapid soil production and weathering in the Western Alps, New Zealand. Science 343:637-640

Matsumoto K, Yokoyama $Y(2013)$ Atmospheric $\Delta^{14} C$ reduction in simulations of Atlantic overturning circulation shutdown. Global Biogeochem Cycles 27:1-9. doi:10.1002/gbc.20035

Matsushi Y, Wakasa S, Matsuzaki H, Matsukura Y (2006) Long-term denudation rates of actively uplifting hillcrests in the Boso Peninsula, Japan, estimated from depth profiling of in situ-produced cosmogenic ${ }^{10} \mathrm{Be}$ and ${ }^{26} \mathrm{Al}$. Geomorphology 82:283-294

Meyer H, Hetzel R, Fügenschuh B, Strauss H (2010) Determining the growth rate of topographic relief using in situ-produced ${ }^{10} \mathrm{Be}$ : a case study in the Black Forest, Germany. Earth Planet Sci Lett 290:391-402

Moon S, Chamberlain CP, Blisniuk K, Levine N, Rood DH, Hilley GE (2011) Climatic control of denudation in the deglaciated landscape of the Washington Cascades. Nat Geosci 4:469-473

Niemi NA, Oskin ME, Burbank DW, Heimsath AM, Gabet EJ (2005) Effects of bedrock landslides on cosmogenically determined erosion rates. Earth Planet Sci Lett 237:480-498

Nishiizumi K (2004) Preparation of ${ }^{26}$ Al AMS standards. Nucl Instrum Methods Phys Res B 223:388-392

Nishiizumi K, Lal D, Klein J, Middleton R, Arnold JR (1986) Production of ${ }^{10}$ Be and ${ }^{26} \mathrm{Al}$ by cosmic rays in terrestrial quartz in situ and implications for denudation rates. Nature 319:134-136

Nishiizumi K, Imamura M, Caffee MW, Southon JR, Finkel RC, McAninch J (2007) Absolute calibration of ${ }^{10} \mathrm{Be}$ AMS standards. Nucl Instrum Methods Phys Res B 258:403-413

Portenga EW, Bierman PR (2011) Understanding Earth's eroding surface with ${ }^{10} \mathrm{Be}$. GSA Today 21:4-10

Portenga EW, Bierman PR, Rizzo DM, Rood DH (2013) Low rates of bedrock outcrop erosion in the central Appalachian Mountains inferred from in situ ${ }^{10}$ Be. Geol Soc Am Bull 125:201-215

Riebe CS, Kirchner JW, Granger DE, Finkel RC (2000) Erosional equilibrium and disequilibrium in the Sierra Nevada, inferred from cosmogenic ${ }^{26} \mathrm{Al}$ and ${ }^{10} \mathrm{Be}$ in alluvial sediment. Geology 28:803-806

Rixhon G, Braucher R, Bourles D, Siame L, Bovy B, Demoulin A (2011) Quaternary river incision in NE Ardennes (Belgium) - insights from ${ }^{10} \mathrm{Be} /{ }^{26} \mathrm{Al}$ dating of river terraces. Quat Geochronol 6:273-284

Rodés Á, Pallàs R, Braucher R, Moreno X, Masana E, Bourlés DL (2011) Effect of density uncertainties in cosmogenic ${ }^{10} \mathrm{Be}$ depth-profiles: dating a cemented Pleistocene alluvial fan (Carboneras Fault, SE Iberia). Quat Geochronol 6:186-194

Schaller M, von Blanckenburg F, Hovius N, Kubik PW (2001) Large-scale erosion rates from in situ-produced cosmogenic nuclides in European river sediments. Earth Planet Sci Lett 188:441-458

Shimizu F, Oyagi N (1988) Landslide map, vol 6. Technical Note No. 125, NIED, Tsukuba, Japan
Shiroya K, Yokoyama Y, Matsuzaki H (2010) Quantitative determination of longterm erosion rates of weathered granitic soil surfaces in western Abukuma, Japan using cosmogenic ${ }^{10} \mathrm{Be}$ and ${ }^{26} \mathrm{Al}$ depth profile. Geochem J 44:E23-E27

Shiroya K, Yokoyama Y, Obrochta SP, Harada N, Miyairi Y, Matsuzaki H (2013) Melting history of the patagonian ice sheet during termination I inferred from marine sediments. Geochem J 47:107-117

Siame LL, Bellier O, Braucher R, Sebrier M, Cushing M, Bourles D, Hamelin B, Baroux E, de Voogd B, Raisbeck G, Yiou F (2004) Local erosion rates versus active tectonics: cosmic ray exposure modelling in Provence (south-east France). Earth Planet Sci Lett 220:345-364

Siame LL, Angelier J, Chen RF, Godard V, Derrieux F, Bourles DL, Braucher R, Chang KJ, Chu HT, Lee JC (2011) Erosion rates in an active orogen (NE-Taiwan): a confrontation of cosmogenic measurements with river suspended loads. Quat Geochronol 6:246-260

Stone JO (2000) Air pressure and cosmogenic isotope production. J Geophys Res 105:23753-23759

von Blanckenburg F (2005) The control mechanisms of erosion and weathering at basin scale from cosmogenic nuclides in river sediment. Earth Planet Sci Lett 237:462-479

Wittmann H, von Blanckenburg F, Maurice L, Guyot JL, Kubik PW (2011) Recycling of Amazon floodplain sediment quantified by cosmogenic ${ }^{26} \mathrm{Al}$ and ${ }^{10} \mathrm{Be}$. Geology 39:467-470

Yamamoto T (2005) The rate of fluvial incision during the Late Quaternary period in the Abukuma Mountains, northeast Japan, deduced from tephrochronology. Is| Arc 14:199-212

Yokoyama Y, Esat TM (2011) Global climate and sea level: enduring variability and rapid fluctuations over the past 150,000 years. Oceanography 24:54-69

Yokoyama Y, Aze T, Murasawa H, Matsuzaki H (2005) Terrestrial Cosmogenic Nuclides as a tool for studying earth surface processes. J Geol Soc Jpn 111:693-700

doi:10.1186/2197-4284-1-9

Cite this article as: Nakamura et al:: Direct comparison of site-specific and basin-scale denudation rate estimation by in situ cosmogenic nuclides: an example from the Abukuma Mountains, Japan. Progress in Earth and Planetary Science 2014 1:9.

\section{Submit your manuscript to a SpringerOpen ${ }^{\odot}$ journal and benefit from:}

- Convenient online submission

Rigorous peer review

- Immediate publication on acceptance

- Open access: articles freely available online

- High visibility within the field

- Retaining the copyright to your article

Submit your next manuscript at $>$ springeropen.com 